\title{
GCU
}

Glasgow Caledonian

University

University for the Common Good

\section{Historical experiences of migration in political discourse in Greece: using critical discourse analysis to explore policy legitimation}

Karamanidou, Eleni

Published in:

Middle East Journal of Refugee Studies

DOI:

10.12738/mejrs.2017.2.2.0114

Publication date:

2017

Document Version

Publisher's PDF, also known as Version of record

Link to publication in ResearchOnline

Citation for published version (Harvard):

Karamanidou, E 2017, 'Historical experiences of migration in political discourse in Greece: using critical

discourse analysis to explore policy legitimation', Middle East Journal of Refugee Studies, vol. 2, no. 2, pp. 161181. https://doi.org/10.12738/mejrs.2017.2.2.0114

\section{General rights}

Copyright and moral rights for the publications made accessible in the public portal are retained by the authors and/or other copyright owners and it is a condition of accessing publications that users recognise and abide by the legal requirements associated with these rights.

Take down policy

If you believe that this document breaches copyright please view our takedown policy at https://edshare.gcu.ac.uk/id/eprint/5179 for details

of how to contact us. 


\title{
Historical Experiences of Migration in Political \\ Discourse in Greece: Using Critical Discourse Analysis to Explore Policy Legitimation
}

Lena Karamanidou ${ }^{a}$

\begin{abstract}
Histories of migration are connected to the development of collective identities and the articulation of discourses of belonging in many national contexts. They are also often employed in legitimating policies on migration, asylum and integration in many national contexts. Critical Discourse Analysis, as a methodological approach inherently concerned with relations of power and the dynamics of exclusion, is particularly suited to exploring how references to past experiences of migration are used in parliamentary debates to legitimate or delegitimate migration policies. Greece, a country where histories of emigration and reception of ethnically Greek refugees are central to constructions of national identity, is used as a case study. Drawing on the analysis of twenty parliamentary debates on eight different laws on migration and asylum, I argue that the invocation of past experiences of migration is both instrumental and ambivalent. All parties, regardless of their political orientation, employ them to either legitimate or critique proposed policies. However, the analysis shows that historical experiences of migration are used to create both narratives of similarity as well as difference between the experiences of immigrants to Greece and Greek emigrants. They are thus used to argue both for the inclusion and exclusion of migrants. In addition, invocations of past experiences of migration reproduce the imagined national community.
\end{abstract}

Keywords

Migration • History $\bullet$ Political discourse $\bullet$ Policy legitimation $\bullet$ Greece

a $(\varangle)$ Lena Karamanidou $(\mathrm{PhD})$, Visiting Fellow in the School for Business and Society, Glasgow Caledonian University. Email: lena.karamanidou@gmail.com

Received: November 20, 2016

Revision received: December 29, 2016

Accepted: January 18, 2017

Online First: September 15, 2017
Copyright @ 2017 • The International Refugee Rights Association • http://mejrs.com/en

ISSN $2149-4398 \cdot$ eISSN $2458-8962$

DOI 10.12738/mejrs.2017.2.2.0114 • Summer $2017 \cdot 2(2) \cdot 161-181$ 
The impact of immigration and asylum seeking on the construction of national identities, political incorporation, and cultural belonging has been a key concern of scholarship on migration (for example Guild, Groenendijk, \& Carrera, 2011; Joppke, 1998). Less attention has been paid not only to how histories of migration affect relations between citizens and migrants, but also to how they interrelate with the formation of identities and policies of incorporation and integration (Glynn \& Kleist, 2012). However, migration histories are enmeshed in the development of collective identities and the articulation of discourses of belonging, and in the legitimation of policies on migration asylum and integration (Glynn \& Kleist, 2012; Tormey, 2007). In this article, I explore how past experiences of migration are used to legitimate or delegitimate asylum and migration policies in Greek parliamentary debates. Experiences of emigration, forced displacement, and resettlement of ethnically Greek populations have not only been crucial in narratives of national identity, but have also influenced discourses, attitudes, and policies toward immigrants and refugees during Greece's transformation into a country of settlement and transit.

Histories of migration, like other forms of collective memories (Gray, 2004; Glynn \& Kleist, 2012) have influenced formations of national identities and belonging in diverse settings. In countries such as the United States or Australia, histories of migration are part of foundational myths and nation-building processes (Kleist, 2012). In other contexts, histories of emigration feed into constructions of national identities that incorporate the diasporic identities of those who have emigrated through sharing ethnic and cultural characteristics (Kincaid, 2009; Low, 2012; Núñez, 2002; Roberts, 2005). Past migrations can be constructed as heroic, whereby migrants voluntarily migrate in order to contribute to the economic wellbeing of their family and country, or traumatic, being involuntary in nature and triggered by economic need or dramatic events (Glynn \& Kleist, 2012; Gray, 2004; Kincaid, 2009; Núñez, 2002). Official narratives are often reproduced through commemorations of historical events or cultural productions, such as museums, public monuments, and literature (Glynn \& Kleist, 2012; Roberts, 2005). However, histories of migration are not only top-down, state-sponsored narratives. Research has shown that remembering and engaging with experiences of migration is crucial for dealing with traumatic events often at the root of displacement, such as the Holocaust (Gershon \& Wolf, 2009), the Irish Famine (Glynn \& Kleist, 2012; Gray, 2004), or the Second World War (Burrell, 2006; Damousi, 2013). Remembering experiences of migration is also a process of making sense of identities transformed by movement, and creating spaces of belonging in places of settlement (Clary-Lemon, 2010; Damoussi, 2013; Roberts, 2005).

Narratives of past migrations equally affect the way that migrants are included or excluded in countries of settlement, especially when invoked in public discourse and policy making processes (Glynn \& Kleist, 2012). They can provide social actors 
with blueprints for action - for example in migration or integration policy - based on "lessons from the past" (Brandsrtom et al., 2004 as cited in Glynn \& Kleist, 2012, p. 9). Consequently, historical experiences of migration are often invoked in political and media debates on migration in support or in opposition of specific policies. References to - often idealized - past experiences of displacement or refugee reception have been used to legitimate policies in settings as diverse as the UK, Australia, Austria, and Germany (Kleist, 2012; Kushner, 2006; Steiner, 2000). In the Irish context, "historical duty" arguments, where traumatic historical experiences of emigration are believed to create moral obligations for the fair and humanitarian treatment of refugees and migrants, have been widely employed in political and media discourse (Glynn \& Kleist, 2012; Lentin, 2003; Tormey, 2007).

This is not to suggest that such discourses are fixed or unchangeable (Glynn \& Kleist, 2012, p. 6). They change over time, in tandem with reconceptualizations of national identity and the politics of migration and belonging. They are also diverse, since different groups construct their own narratives of past migrations, which can be negotiated by gender, class and place (Glynn \& Kleist, 2012; Gray, 2004). Equally, references to the past do not always support liberal migration policies or greater inclusion. While Lentin (2003) argued that addressing the trauma of histories of emigration could create the space for accepting the migrant Other, Gray noted that Lentin's approach risked homogenizing different experiences of emigration and obscuring the existence of contradictory narratives on them. The idealization of "our" migration experiences can in fact result in the exclusion of the migrants, since "true" experiences of emigration are identified with the in-group (Glynn \& Kleist, 2012; Gray, 2004) while the migrant Other is negatively associated with criminality, cultural difference, and threats to identity and security. Similarly, Tony Kushner (2006) has demonstrated that constructions of historical experiences of refugeeness in the UK tend to construct "deserving" and "undeserving" refugees. The use of historical duty arguments can also be purely rhetorical (Glynn \& Kleist, 2012; Tormey, 2007; Van der Valk, 2003) and can decrease over time, as perception of moral duty decline in the face of increased migration flows (Glynn \& Kleist, 2012; Steiner, 2000).

Consistently with the methodological emphasis of the issue, I use critical discourse analysis, a method well suited for the study of political discourse in general, and political argumentation in particular. Drawing on the analysis of 20 parliamentary debates on 8 different laws on migration and asylum, I demonstrate that references to collective migration experiences are not only employed to argue for greater tolerance or inclusiveness, but also for greater exclusion. They also reproduce positive representation of the Greek in-group and hegemonic discourses of national identities. While Greece is a highly specific context, the dynamics of historical migration experiences are of particular significance in the Eastern Mediterranean context. As 
mentioned in the introduction to this issue, the Eastern Mediterranean context is characterized by traumatic histories of displacement and resettlement - most recently with the Syrian refugee crisis, but also by recent histories of emigration. This article hopes to illustrate how critical discourse analysis can highlight their relevance for contemporary political debates on migration.

\section{Methodology: Critical Discourse Analysis and Legitimation}

Critical Discourse Analysis (CDA) is particularly suited to the study of historical and contemporary migration and displacement, especially in what concerns the interaction between policies, politics, and discourses. CDA has its roots in the Critical, Marxist, and Foucauldian traditions, and aims at revealing how relations of hegemony, power, and dominance are articulated and legitimized in discourse (Fairclough, 2003, 2009; Reisigl \& Wodak, 2009). As the introduction to this issue notes, the field of forced migration is dominated by manifestations of state power, expressed both in representations of migration and migrants, and in the articulation of solutions to refugee issues. Using CDA, researchers have interrogated how refugees and migrants are problematized in political and media discourses. For example, labeling migrants as "refugees," "asylum seekers," or "illegal immigrants" in discourse is also an exercise of political power, an act of categorization that facilitates the exercise of control over migration, and can limit refugees' access to refugee protection (Gabrielatos \& Baker, 2008; Karamanidou, 2007; Khosravinik, 2009; Zetter, 2014). Equally, CDAinformed approaches explore the expression of inclusion and exclusion in discourse (Wodak, 2011; Wodak, de Cillia, Reisigl, \& Liebhart, 2000).

A further strength of CDA lies in its conceptualization of discourses and context. For CDA, discourses are produced in specific social, political, and institutional contexts. Discourses on migration, from this perspective, are shaped not only by existing policy and legal frameworks, but also by institutional arrangements and both the agendas and ideologies of political actors. Social practices and discourse as dialectically interconnected, since social practices can frame and alter discourses, and discursive events can shape social practices (Fairclough, 2003; Reisigl \& Wodak, 2009). Discourses are seen as ontologically distinct from social contexts, adopting a critical realist, rather than postmodern ontology. Therefore, CDA focuses on the examination of the dialectical relationship between discursive acts and the situations, institutions, and social structures and practices. In terms of techniques, this involves both the analysis of linguistic features of texts such as actor descriptions or representations of social processes, and discursive strategies (Fairclough, 2003; Reisigl \& Wodak, 2009). The analysis of discourses of migration and asylum might draw, for example, on the study of actors descriptions, such as the use of pronouns or labels or strategies of positive self-presentation and negative Other-presentation 
that designate and reproduce the dichotomy "us" and "them" of in-groups and outgroups (e.g. Triandafyllidou, 2000; Wodak, 2011). The task of CDA is to interpret their meaning within the contexts they are produced in relation to intertextuality and interdiscursivity - relations to other texts and discourses which extend to the past as well as the present (Reisigl \& Wodak, 2009; Wodak et al., 2000). Present discourses on migration are also shaped by longer-term narratives of "home," national identity and belonging. These constitute shared social knowledge (van Dijk, 2014) and are particularly important in understanding not only histories of emigration and diasporic identities, but also the way they are used in political discourse.

Political discourse is used to argue and justify, to legitimate policy choices, to serve interests its functional qualities include coercion, manipulation, persuasion, dissimulation, legitimation and delegitimation (Chilton \& Schäffner, 1997; Fairclough \& Fairclough, 2012; van Dijk, 1997). While it can shape social and political representations and solutions to social and political issues, it is also instrumental, through argumentation, in legitimating policy responses to them (Fairclough \& Fairclough, 2012; Reisigl \& Wodak, 2009). References to a collective migration past are an element of discursive legitimation - the process of arguing for or against courses of action because they adhere to shared norms and values (Fairclough \& Fairclough, 2012). Legitimation by referring to history is one of the most common legitimating strategies (Fairclough, 2003; Van Leuwen \& Wodak, 1999). Thus, references to a collective history of emigration act as a legitimating myth (Sibley, Liu, Duckitt, \& Khan, 2008), a form of authorization that claims legitimacy for a speaker's position through evoking the authority of traditions and values bestowed by a common past.

The research draws on the genre of parliamentary debates because they represent political discourse and because of its central features of argumentation and legitimation (Van Dijk, 1997). The debates (Table 1) were selected because they are all on key legislation introduced in the fields of asylum, immigration, and citizenship and because they allow the presence and intensity of references to a collective past over time to be examined. The first two debates correspond to the introduction of the first asylum law in 1996, while the last three debates concern the codification of migration control and immigration laws in 2014. I adopted a deductive/inductive approach to develop analytical categories. Based on the literature, I classified relevant content as legitimation or delegitimation, applying the distinction between logics of equivalence and difference (Fairclough, 2003). The first refer to strategies of building commonalities between social phenomena or groups by "subverting differences and divisions" (Fairclough, 2000) - in this case contemporary migrants to Greece and Greeks as historical migrants. Conversely, a logic of difference refers to strategies of maintaining divisions by differentiating the experiences of Greek emigrants or refugees from those of migrants to Greece. Two further analytical categories were 
applied: (1) government or opposition, and (2) political party, since it was of interest to see the relation between political/ideological orientation, party position, and employment of references to historical experiences of emigration. A list of political parties and composition of Greek governments are provided in Table 2.

\section{Exploring Constructions of an Emigrant Past in the Greek Context}

Greece is often seen as a "new" country of immigration. While small numbers of migrants settled in Greece in the 1970s, immigration intensified in the 1990s following the collapse of communist regimes in the Balkans and Eastern Europe. Migrants from the former Soviet Union republics and countries in the Balkans and Eastern Europe - predominantly from Albania settled in Greece (Kasimis, 2012; Triandafyllidou \& Maroukis, 2012). These flows also included ethnically Greek returning migrants, such as members of the Greek minority in Albania and Greek post-civil war refugees who had settled in Soviet Republics and Eastern European Communist states. Since the 2000s, however, trends have reflected the dynamics of armed conflict and political instability in Asia, Africa, and the Middle East (Triandafyllidou \& Maroukis, 2012), as is most recently exemplified by the Syrian refugee crisis. Because of its geographical position, Greece is both a main point of entry into the European Union and a country of settlement and transit (Kasimis, 2012; Triandafyllidou \& Maroukis, 2012).

However, complex patterns of emigration, forced migration and reception have been intrinsically linked with the history of Greece. Nearly one-sixth of the Greek population emigrated to Europe, Egypt, and the USA in the late $19^{\text {th }}$ and early $20^{\text {th }}$ century following the 1893 economic crisis. At the same time, Greece received a high number of refugees who were or at least were perceived as ethnically Greek - in the late $19^{\text {th }}$, and more intensely in the first half of the 20th century. Pontic populations settled in Greece after leaving Turkey during the nation-building processes there. In 1923, following the defeat of the irredentist military expedition of the Greek army, an exchange of populations was agreed between the Greek and Turkish states. As a result, approximately 1.5 million refugees from Asia Minor settled in Greek territories (Triatafilopoulos, 2003; Voutira, 2003). Between the end of the second World War and the 1970s, an estimated one million emigrated to industrialized countries - mostly to Germany, the US, Australia, and Canada (Kasimis, 2012; Mousourou, 2003). Labor migration, similarly to other countries, was encouraged by the state in order not only to alleviate pressures by unemployment, but also to aid economic development through remittances (Mousourou, 2003). In addition, being on the losing side of the Greek Civil War, around 65,000 Greeks became refugees in Eastern bloc countries, (Kasimis, 2012; Mousourou, 2003). Smaller numbers took refuge in European countries following the military dictatorship of 1967 (Kasimis, 2012; Mousourou, 2003). 
Refugee and emigrant identities have become part of narratives of national identity. Despite initial difficulties and hostile attitudes, the successful settlement and integration of the Asia Minor refugees integration led to a "remarkable consensus among scholars, politicians and refugees on the post 1923 settlement as a major 'success' case" (Triatafilopoulos, 2003; Voutira, 2003, p. 71). Such hegemonic narrations are intrinsically linked to the construction of nationalist narratives of history, and the refugee identity has been identified with Greek historical experiences. Similarly, post war labor migration was discursively constructed both as an occasion of national trauma and as a "success story" (Laliotou, 2010; Sapountzis, Figgou, Bozatzis, Gardikiotis, \& Pantazis, 2013; Vogli, 2011). It reflects nationalist politics of diaspora and the omogeneia - Greek populations outside the national space who both promote national interests and maintain their Greek ethnicity and culture outside the national space (Christou, 2006; Koukoutsaki-Monnier, 2012). Like in other national histories, experiences of emigration produce the figure of the heroic, entrepreneurial, and hardworking diasporic migrant, who contributed both to his country of origin and destination while still maintaining their Greek identity (Laliotou, 2010; Sapountzis et al., 2013; Vogli, 2011).

These historical events have had a significant impact on refugees and immigrants. For example, Voutira (2003) argued that since forced migration has been identified with the Greek historical experience and identity, refugees and asylum seekers without such a claim are treated with suspicion and hostility, and seen as undeserving of recognition and protection. Moreover, these perceptions influenced immigration policies. Immigrants of ethnic Greek origin were differentiated from "foreign" ones and are aided by specific policies, such as housing and language lessons, addressed specifically to them (Triandafyllidou \& Veikou, 2002; Voutira, 2003). More importantly, while the state encouraged the naturalization of ethnically Greek immigrants, it made it extremely difficult for non-ethnically Greek immigrants to acquire citizenship (Konsta \& Lazaridis, 2011).

At the same time, the Greek experience of emigration and of being a refugee can promote inclusive attitudes, discourses, and policies. While similar research in the Greek context is limited, there is some evidence that this approach has been used by centre leftist media and politicians (Christopoulos, 2004; Tzanelli, 2006), and that individuals use the collective experience of emigration to support a more positive stance toward immigrants (Sapountzis et al., 2013), through a critical re-examination of the diversity of Greek histories of migration (Laliotou, 2010). However, responses to such arguments, as Tzanelli (2006) shows, allude to the difference between the experiences of Greek migrants and immigrants to Greece. Overall, one's own experiences of emigration and being a refugee have not always translated into that person developing positive attitudes toward immigrants, refugees, and asylum seekers 
since the emigrant experience is identified with the host community (Sapountzis et al., 2013; Triandafyllidou, 2000).

In this article, I explore to what extent these histories of migration are invoked in the process of policy-making on migration and asylum. Migration has been a highly politicized issue in Greece since the increase of migration trends in the 1990s. While migrants, especially for Balkan and Eastern European countries, provided flexible, cheap, and easily exploited labor that served the needs of the Greek economy in the 1990s and 2000s, migration itself was associated with criminality and illegality (Triandafyllidou \& Maroukis, 2012). Unauthorized migration flows into Greece in particular were constructed as threats to the cultural identity and security of the country (Karyotis, 2012; Triandafyllidou \& Maroukis, 2012), in parallel with an emphasis on preventing migration flows in the context of EU migration policies. In addition, the Greek citizenship regime is underpinned by a conception of national identity based on shared culture and common descent remained largely exclusionary toward migrants. The ongoing austerity crisis intensified processes of othering as well as racist and xenophobic attitudes, associated with the rise of far right parties such as LAOS and Golden Dawn (Triandafyllidou \& Kouki, 2014). The SYRIZA government, elected in 2015, adopted a considerably less hostile discourse toward migrants, and at least initially, a distinctly humanitarian discourse toward Syrian refugees. However, the dynamics of the Syrian refugee crisis, the EU management of the crisis and the pressures it engenders for Greece, as well as the continuing austerity measures work to perpetuate social and political tensions around migration. These tensions provide the social and political context to the debates analyzed here.

\section{Analysis}

A first observation in relation to the data is that references to refugee and emigrant experiences are present in all parliamentary debates on the introduction of asylum and immigration legislation. The majority of references to historical experiences of migration were made by speakers of the center left PASOK and European left SYRIZA, represented as a governing party only in 2015. While this is partly due to the longer time that PASOK was in government, comparisons of debates suggest that this is not the only reason. For instance, PASOK MPs made 6 references in the two 2001 Immigration Law debates, while New Democracy MPs made only 2 in the four debates on the similar-in-nature 2005 Law. This relative absence is not entirely surprising; as an opposition party supporting law and order policies, they were unlikely to invoke moral obligations and argue for more inclusionary policies.

\section{Legitimating and delegitimating policies: Historical duty arguments.} References to a collective past of emigration and forced displacement are often employed to suggest that policies are justified because they are guided by the moral obligations dictated by these collective experiences and identities: 
[1] [...] our Country is a country that, possibly because it could not feed all its population, had, from ancient times onwards, out-going migration. And this must make us show understanding towards those who, mainly for reasons of sustenance, enter our country, regardless of how serious the consequences on the economy of the country might be, especially on the problem of employment. (December 11, 1996, 1784, PASOK)

[2] As a formerly sending country, Greece must be particularly sensitive in its management of the immigration problem. (March 06, 2001, evening, p. 5639, PASOK)

[3] We Greeks have a very important reason to do so [introduce the migration law], because our compatriots in other times, during our long history, had, for different reasons, to abandon their homeland and experience similar situations to those that unfortunately, tragically, immigrants experience today in our country and other countries. (August 02, 2005, 651, New Democracy)

[4] The issue is for the country to obtain a modern [legal] framework, which will completely respect human rights, will be harmonized with European acquis, with Greek culture - if you want - with Greek history, since we were migrants before we gave hospitality to migrants in our country. (March 19, 2014, 8836, New Democracy)

[5] I think the long term experience of the Greek diaspora can be very useful in developing policies of integration [...] This law has greater value because, in retrospect, it provides restitution for all the injustices, the pain, and the humiliations that Greek migrants, our grandfathers, were subjected to in all latitudes and longitudes, from very distant times to the present. As a people of emigrants, we should not forget the "Except Greeks and dogs" signs outside restaurants in 1920s America, the ghettos of Greek guest workers in Germany, and the recent crisis, which has led thousands of our young people abroad. (June 24, 2015, 3708, Syriza)

In all extracts, speakers legitimate the proposed policies by alluding, explicitly or implicitly, to moral obligations dictated by collective past experiences of emigration. References to history are powerful rhetorical devices (Wodak et al., 2000; Van Leeuwen \& Wodak, 1999) because they construct shared understandings and legitimate present courses of action by invoking continuity between past and present. These processes are evident in the above extracts by speakers of governing parties, who utilize historical duty arguments to support proposed laws. Experiences of migration constructed as shared through the use of collective actor descriptions (Wodak et al., 2000; Van Dijk, 1993). Speakers use of the first person plural - "we" "our," - collective actor designations such as "we Greeks," and metonymy and personification of the country - "Greece" "our county" - appearing as subjects of sentences. By representing experiences as shared and universal, speakers construct consensus and increase the strength of the legitimation moves (Van Dijk, 1993).

Equally, collective experiences of emigration are identified with Greek history, both ancient as in extracts 1, 3, and 4, and recent as in extracts 3 and 6. However, speakers create connections between the historical past and Greek present. Extracts [1] and [3] reflect the perception that there is an uninterrupted link between ancient and 
modern Greece, which is one of the main tenets of Greek nationalism (Christopoulos, 2004; Tzanelli, 2006). In the first two extracts, speakers evoke the Greek history of emigration to suggest the values that should underpin attitudes to migrants and migration policy making; namely, "sensitivity" and "understanding." These were invoked frequently in parliamentary debates on asylum and immigration in Greece (Karamanidou, 2010), especially in the context of strategies for representing the ingroup. Extract 4 associates history with culture, and positively evaluates the proposed law as living up to both. Thus, such references both derive from and reaffirm already existing ideas that shape national Greek identity, such as the continuity of the Greek nation. Extract 5 differs insofar as it was articulated in a context when emigration had intensified because of the austerity crisis whereas at the time of the other debates, emigration was seen as a past experience. It also articulates a very strong historical duty argument in relation to the 2015 Citizenship Law regulating the naturalization and integration of second generation migrants. The experiences that Greek emigrants lived through; namely, racism and marginalization, inform us of the speaker's desire that immigrants in Greece not be subject to the same injustices.

However, "historical duty" arguments are equally used by left wing parties to delegitimate policies by arguing that they do not live up to the moral obligations dictated by the past. This is not only true for PASOK while it was the opposition party during the 2005 Immigration law debates, but also for the Greek Communist Party (KKE), the Coalition of Radical Left (SYRIZA, 2004- ), and its precursor, the Coalition of the Left and Progress (SYN, 1991 - 2003).

[6] [...] we Greeks must be especially sensitive in this matter, because in the turbulent recent history of our country, our People and especially those who fought for the ideals of democracy, of freedom, of social progress, unfortunately has the misfortune, let me put it like this, to be persecuted and to take refuge abroad, where they had the chance to taste the warmth of international solidarity. (December 11, 1996, 1785-6, KKE)

[7] You have opportunity, instead of suppressing the different, to integrate it into the social fabric. To break the racist stereotypes that poison Greek society. A society that has nearly forgotten, with all these posturing of hate speech, that our grandfathers were refugees and our fathers emigrants. (March 10, 2010, 4784, SYR)

[8] We, with every one of our families' having relatives abroad, have been listening our parents talk about being in foreign lands [xenitia], sing about xenitia, ever since we were young. Shouldn't we be a lot more generous with people who are forced to seek shelter in our country on their way to Europe? (March 20, 2014, 9097, SYR)

Although the linguistic means used to express this realization are very similar - collective actor descriptions and invocations of past experiences in a very emotive manner in extract [6]-, they serve a completely different argumentation. The speakers of these extracts all voted against the proposed legislation, and employed historical 
duty arguments to argue that the proposed legislation did not live up to the moral obligations dictated by past experiences of emigration and of being a refugee. The use of references to past experiences of migration for entirely different purposes both for legitimating and delegitimating policy - suggests that these histories, while shared through hegemonic narratives, assume "flexible" meanings, constructed in conjunction with the political identities of the speakers. They reflect their political orientation vis-a-vis migration policies, but are also used for rhetorical, instrumental purposes. Speakers of PASOK and SYRIZA invoke, for example, histories of migration both as the governing and opposition party, to support, especially in the case of the former party, migration policies oriented toward control and deterrence.

While normally references to the past invoke a historical duty argument - how policy ought or ought not to be, this argument occasionally slips into categorical statements about qualities endowed by past experiences of migration. For instance, a speaker in the 1996 debates links the possession of a refugee identity to the "natural" superiority of Greek responses to migration.

[9] The term refugee [...] is very familiar to us, synonymous to our historical process [...] Our Eastern Mediterranean and refugee identity constituted a significant foundation for our ability to face, as a nation and in terms of Greek policy, the challenge of the most severe law, which is the right of the nations, the universal declaration of human rights and the national fights for liberation. (December 11, 1996, 1777, PASOK)

The speaker draws on discourses of national identity that have incorporated the experience of being a refugee -specifically refugees from Asia Minor. Rather than making normative claims about the proposed law, he suggests that the commonly held "refugee identity" bestows Greece with the right qualities to face challenges posed by migration. In linguistic terms, the latter is suggested by the use of categorical modalities (Fairclough 2003). Evoking past experiences of migration is also employed in conjunction to denials of racism:

[10] Greek society [...] is not a xenophobic society, is not a racist society [...] Let us not forget that millions of Greek men and women have been migrants, refugees, exiles. We know what being a refugee is, we know the immigrant's pain. (March 11, 2010, 4918, ND)

[11] [...] our country, friends, is an open and democratic country which condemns racist views and tendencies, anywhere they might come from, a country that has long and bitter migrant experience, since until a few years ago, was a sending country of Greek emigrants. (March 11, 2010, 4816, ND)

[12] It is the responsibility of all of us to show that Greeks, a people who know very well what refugeeness and migration mean, are not, and will never be racist. (July 24, 2015, 3716, River)

[13] Archaeologists in Akrotiri in Santorini discovered a mural which, like a graphic novel, presents the following story: the number of inhabitants were more than the place could feed 
and every family had to nominate a member, and all of them, after getting the necessary supplies, boarded ships and left for somewhere else [...]Such a people with all of this written in their DNA and all that they've been through therefore cannot today be racist or xenophobic. (January 12, 2011, 3473, PASOK)

As in previous extracts, speakers employ such collective actor representations as the words "our" and "country," the latter repeated four times, to attribute such positive attributes as openness, democracy, and lack of racism to the national community. They are examples of positive-self presentation - a semantic and rhetoric strategy which permits speakers to present themselves or the group with which they identify in a positive light in terms of values, attitudes, and actions (Van Der Valk, 2003; Van Dijk, 1997). While racism is evident not only in political and media discourse, but also social practices (Dalakoglou, 2013; Triandafyllidou \& Kouki, 2014), denials of racism are a common rhetorical feature of discourses of migration and strategies of positive self-presentation (Triandafyllidou, 2000; Van Dijk, 1993). Here, the perceived lack of racism is attributed to historical experiences of emigration, implicitly in the first two extracts and explicitly in the third. Invoking the authority of history enhances appeals to legitimacy, and as the next section will demonstrate, sharpens the contrast between a positively represented in-group and a negatively represented out-group.

Legitimating policy: Logics of equivalence and difference. References to historical migration experiences often entail constructing similarities and differences between Greek emigrants and refugees on the one hand, and immigrants and refugees to Greece, on the other. While parties on the left of the political spectrum have developed a logic of equivalence and emphasize similarities, parties on the political right emphasize dissimilarities, adopting a logic of difference. Parties on the left PASOK, SYRIZA and KKE - represent the experiences of Greek emigrants and immigrants to Greece as similar. The following extracts exemplify this strategy:

[14] They [immigrants] do the jobs that our compatriots do not want to do, just like our own fellow citizens did when they emigrated to Central Europe, and more specifically [when they emigrated] to Germany, Sweden, and Belgium. (March 06, 2001, 5603, SYN)

[15] The law has a particular meaning because it highlights the sacrifices of the first generation of migrants who, dreaming of a better life for the children, put their own needs and plans, and in many cases, their human rights second. This is exactly what our grandfathers and parents did when they migrated to secure better living conditions for their children. (July 08, 2015, 4197, SYRIZA).

[16] [...] The Greek citizen is crushed by bureaucracy. Is it possible for migrants, who don't know the language, who are strangers in this place, who are afraid, to claim their rights? We have known migration to Germany and have heard descriptions by people who are today pensioners in the German public service, about the awe of the first contact and about how they would be treated by the German bureaucracy, where I can say that bureaucracy and state work much better than ours. (August 03, 2005, 717, PASOK) 
In all extracts, speakers draw parallels between the experiences of Greek emigrants and immigrants in Greece. The first quotation compares the role of immigrants in the job market to that of Greek emigrants to industrialized European countries in order to refute fears that immigrants create unemployment. Similarly, the second extract draws similarities between the experiences of first generation Greek migrants and immigrants in Greece in order to support the liberalization of the citizenship regime with the 2015 Law. While both of these extracts are fairly straightforward examples of drawing on historical experiences in order to support inclusion, the third extract illustrates how such references can also discursively exclude migrants. While the speaker draws on a logic of equivalence, arguing that contacts with bureaucracy have been difficult for both Greek emigrants and immigrants to Greece, he simultaneously constructs migrants as different "strangers" who do not speak Greek, one of the main markers of belonging to the Greek ethnic group.

Despite any exclusionary undercurrents, mobilizing common experiences allows speakers to argue that migrants should be granted the rights that Greek emigrants were granted in other countries:

[17] Whatever we ask for and are proud of for Greeks abroad, we should have the courage to adopt as treatment toward strangers in Greece, foreign-origin compatriots of ours in Greece [..] we can't have demands for Greeks in Germany, Australia, or any other country and not practice them here in Greece. (March 10, 2010, 4825, PASOK)

[18] We cannot deny them [immigrants] their right to participate in social life. [...] Isn't it hypocritical to entrust them our buildings, our lands, tourism, the care of our parents and children, but to keep them strangers, in a distance and not recognize their right to obtain Greek citizenship? Most of us have relatives who left Greece in very difficult conditions, went to America in search of a better life, and despite all initial difficulties and suspicion, they were given this opportunity. American Society would be poorer, culturally and financially, without the big Greek community of omogeneis who live, work, and often achieve great things there. (March 10, 2010, 4768, PASOK)

The 2010 Citizenship Law attempted to facilitate the acquisition of citizenship by granting immigrants and their children legal resident status. Vehemently opposed by New Democracy and radical right LAOS parties (as extracts in the following section demonstrate), it was presented by the governing PASOK party as a law that rendered the notoriously restrictive citizenship regime fairer, while at the same time promoting integration. In the first extract, the speaker mobilizes the values of fairness by claiming that immigrants should be treated in the same manner that Greek migrants are expected to be treated abroad, alluding to the politics of the Greek state toward Greek diasporas. The second extract also invokes fairness and equality, especially by the use of the word "hypocrisy," but also through references to the consequences of lack of inclusion, contrasted to the eventual successful integration of Greek emigrants. While the argumentation legitimates a policy of greater inclusion, it also reproduces nationalist discourses of the diaspora as a success story (Laliotou, 2010). 
While the mythologies of diaspora in these extracts still serve as arguments in favor of greater inclusion, right-wing parties; namely, the conservative New Democracy and the far right LAOS and Golden Dawn parties, employ references to past experience to construct a logic of difference, presenting Greek emigrants and immigrants to Greece as two entirely different groups.

[19] I have to stress that when Greek migrants went abroad, they went legally, with papers and employment. Those who stayed were the quietest, those who had excellent conduct, and they succeeded. When we talk about illegal immigrants, we should not confuse them and make such comparisons with our own migrants, who indeed went abroad in their thousands. (January 12, 2011, 3467, ND)

[20] Were our Greek parents people who left and wanted to disrespect the principles and values of other peoples and other countries? (March 10, 2010, 4810, LAOS)

[21] [..] When I lived and worked in Germany as a trainee doctor, and worked in German universities, I was legal and paid my taxes and national insurance and resided somewhere and did not steal or assault anyone. Do you know what racism is, minister? It's going to a restaurant to eat and when the German sees you, get up and leaves in response to racial and color differences. Immigrants here have not experienced this. (March 09, 2010, 4753, LAOS)

The above extracts draw on discourses of illegality and criminalization that have dominated the Greek politics of migration over the last twenty years and tend to dominate the discourses of right wing parties, although not exclusively. Migrants are portrayed as "illegal," as threats to employment and cultural identity, and are suspected of criminal activities. While these representations are often stated explicitly, in the above extracts they are mostly implied, expressed through juxtaposition to the positive characteristics of Greek emigrants - lawfully present, law-abiding, and hardworking. In the last extract, immigrants are not only represented in a negative manner, but the speaker denies their experiences of racism and, similarly to Sapountzis et al.'s (2013) findings, the positive representations of Greek emigrants' experiences serve to deny racism and prejudice. Equally, in all the above extracts, the idealized experiences of Greek migrants are adopted as the standard against which the experiences of immigrants are judged, reproducing nationalist perceptions of superiority.

Taking the logic of difference a step further, the overtly nationalist and antiimmigration parties LAOS and Golden Dawn claimed that any comparisons of experiences of Greek emigrants and immigrants to Greece were an "insult" to what they considered a widely shared sense of identity and history:

[22] You use everything to justify your law. The heroic Greek migrants of America, you put them on the same boat as the illegal immigrants, and our uprooted ancestors, the Aivaliots, the Smyrnians, the Pontians, the uprooted Greeks of Turkey, you equate with the illegal immigrants, those pushed by Turkey with the smugglers, earning thousands of dollars per head. (March 10, 2010, 4808, LAOS) 
What is interesting in this extract is the explicit recognition of references to the past as a legitimating strategy - a move that shows the astuteness of LAOS in terms of political rhetoric. The speaker, however, is not averse to invoking past migrations himself. The ritual naming of specific populations displaced in the early $20^{\text {th }}$ century and the parallel negative representation of Turkey evoke nationalist narratives of history where Greek identity is constructed in opposition to the Turkish Other. Equally, the speaker uses highly charged words to enforce the rhetorical power of his statement, such as the word "heroic" for Greek refugees, and the word uprooted [xerizomenoi] which signifies the trauma of displacement. On the day before, criticisms of the law's white paper for "equating of refugees from Pontos and Asia Minor with Pakistanis and Afghans" were accompanied by MPs' shouting "shame" and "disgrace" (March 09, 2010, 4740). Speakers of Golden Dawn, the extreme right party elected in 2012, use the same emotive words to express their rejection of logics of equivalence. The comparison - between "our fathers and our grandfathers, the Greeks" and "the Pakistanis and Afghans and illegal immigrants" is described as an "insult" by a Golden Dawn MP in a debate on the establishment of detention centers (September 27, 2012). In 2015, an MP of the same party states that

[23] It is a shame and disgrace to confuse the Greek diaspora with the illegal immigrants [in Greece]. Our grandfathers who went to work in industrialized countries were migrants, refugees $[\ldots]$ and they took their civilization [politismo] there. Those who come here as illegal immigrants bring no civilization. (July 24, 2015, 3747, Golden Dawn)

The word politismos is often translated as "culture" into English. In this extract, I opted to use the word "civilization" instead, because it reflects the connotations of racial hierarchies that are central to the ideology of Golden Dawn as a party. For them, immigrants are barbaric and "uncivilized." Greeks, in contrast, are constructed as "civilized" - a word that invokes ultra-nationalist discourses on their position as inheritors of Ancient Greek civilization. Comparisons between the two groups are constructed as "shameful" because they do not acknowledge what is self-evident for Golden Dawn; that is, the superiority of Greek culture. The use of historical references by LAOS and Golden Dawn show the continuing significance of experiences of displacement in the reproduction of nationalism.

\section{Conclusion}

Drawing on Greek debates on migration, I demonstrated how CDA can be employed in order to explore how past experiences of migration are invoked to legitimate policies. CDA is, I believe, a strong methodological proposition for exploring discourses on forced migration, since it brings to the fore the mechanics of reproducing hegemonic identities and patterns of inclusion and exclusion. 
All parties refer to past experiences of migration, albeit with varying intensity, demonstrating that historical experiences of migration constitute a form of shared knowledge on which speakers draw in the course of their argumentation. Applying a CDA approach to the Greek case has emphasized how different actors employ past experiences of migration instrumentally (Glynn \& Kleist, 2012; Gray, 2004). Broadly speaking, parties left of center represent the experiences of Greek emigrants and immigrants to Greece as similar in terms of their social roles and positions, developing a discursive logic of equivalence (Fairclough, 2003) in order to argue for equal treatment and rights for migrants. Conversely, members of the parties on the right of the political spectrum - conservative New Democracy, radical right LAOS and Chrysi Avgi - consistently differentiate the experiences of Greek emigrants from those of migrants in Greece in order to delegitimate migration policies. This suggests that narratives of past migrations are not fixed, but whose subject can be altered to fit different political agendas (Glynn \& Kleist, 2012; Gray, 2004). References to past emigration experiences serve instrumental aims of legitimating policies that might be restrictive or exclusionary, or at least present limitations to the degree that they promote the inclusion of migrants. For instance, the 2011 asylum law incorporated the returns directive, thus expanding the provisions for detention and deportation; the 2010 Citizenship Law, while being a step forward for Greek standards, limited its scope to legal immigrants only.

While the invocation of past experiences and historical duties can be seen as an inclusionary discourse (Gray, 2004; Lentin, 2003), CDA helps demonstrate that the extent of this usage should not be overestimated. Speakers discursively reproduce the status of migrants as "strangers," and the experiences of migrants in Greece are primarily seen through Greek experiences of migration, a discursive mode which runs the risk of reproducing unequal social positions. Drawing on discourses of criminalization and illegality that have dominated Greek political debates on migration, right wing parties reproduce migrants not only as the Other to the figure of the successful, lawful, and law abiding Greek emigrant, but as inferior denizens of the country. The ambivalent uses of emigrant experiences in political discourses of migration are similar to the contradictions observed by Sapountzis et al. (2013) in their exploration of everyday discourse in Greece. This distance is widened by associating "real" emigrant and refugee experiences solely with the historical experience of the in-group, while doubting the validity of the current experiences of migrants. In this respect, CDA can demonstrate how such linguistic features as positive self-presentation strategies and the use of collective actors reinforce the boundaries between "us" and "them" (Triantafyllidou, 2000; van Dijk, 1993), reiterating narratives of identity relying on idealized experiences of displacement. References to past experiences of migration not only legitimate and delegitimate policy positions, but reproduce hegemonic narratives of national identity. 


\section{References}

Burrell, K. (2006). Personal, inherited, collective: Communicating and layering memories of forced Polish migration. Immigrants \& Minorities, 24(2), 144-163.

Chilton, P., \& Schaffner, C. (1997). Discourse and politics. In T. A. van Dijk (ed.), Discourse studies. A multidisciplinary introduction. Discourse as social interaction (Vol. 2., pp. 206-230). London, UK: Sage.

Christopoulos, D. (2004). Immigrants in the Greek political community. In M. Pavlou \& D. Christopoulos (Eds.), Greece of immigration: Social participation, rights and citizenship (pp. 338-366). Athens, Greece: Kritiki.

Christou, A. (2006). Deciphering diaspora-translating transnationalism: Family dynamics, identity constructions and the legacy of 'home' in second-generation Greek-American return migration. Ethnic and Racial Studies, 29(6), 1040-1056.

Clary-Lemon, J. (2010). "We're not ethnic, we're Irish!" Oral histories and the discursive construction of immigrant identity. Discourse \& Society, 21(1), 5-25.

Dalakoglou, D. (2013). From the bottom of the Aegean sea to Golden Dawn: Security, xenophobia, and the politics of hate in Greece. Studies in Ethnicity and Nationalism, 13(3), 514-522.

Damousi, J. (2013). Legacies of war and migration: Memories of war trauma, dislocation and second generation Greek-Australians. In N. Steiner, R. Mason, \& A. Hayes (Eds.), Migration and insecurity citizenship and social inclusion in a transnational era (pp. 31-47). London, UK: Routledge.

Fairclough, I., \& Fairclough, N. (2012). Political discourse analysis: A method for advanced students. Hoboken, NJ: Taylor and Francis.

Fairclough, N. (2000). Discourse, social theory, and social research: The discourse of welfare reform. Journal of Sociolinguistics, 4(2), 163-195.

Fairclough, N. (2003). Analysing discourse: Textual analysis for social research. London, UK: Routledge.

Fairclough, N. (2009). A dialectical-relational approach to Critical discourse analysis in social research. In R. Wodak \& M. Meyer (Eds.), Methods of critical discourse analysis (pp. 162-186). London, UK: Sage.

Gabrielatos, C., \& Baker, P. (2008). Fleeing, sneaking, flooding: A corpus analysis of discursive constructions of refugees and asylum seekers in the UK press, 1996-2005. Journal of English Linguistics, 36(1), 5-38.

Gerson, J. M., \& Wolf, D. L. (Eds.). (2007). Sociology confronts the Holocaust: Memories and identities in Jewish diasporas. Durham, UK: Duke University Press.

Glynn, I., \& Kleist, J. O. (2012). History, memory and migration: Perceptions of the past and the politics of incorporation. Basingstoke, UK: Palgrave Macmillan.

Gray, B. (2004). Remembering a 'multicultural' future through a history of emigration: Towards a feminist politics of solidarity across difference. Women's Studies International Forum, 27(4), 413-429.

Guild, E., Groenendijk, K., \& Carrera, S. (2009). Illiberal liberal states: Immigration, citizenship, and integration in the EU. Farnham, UK: Ashgate.

Joppke, C. (Ed.). (1998). Challenge to the nation-state: Immigration in Western Europe and the United States. Oxford: Oxford University Press. 
Karamanidou, L. (2007). Refugees, 'illegal immigrants' and asylum seekers: Use of discursive categories and legitimation of asylum policies in Greek political discourse. Mediterranean Journal of Human Rights, 11(2), 17-45.

Karamanidou, L. (2010). The discursive legitimation of asylum policies in Greece and Ireland (Doctoral dissertation). City University, London.

Karyotis, G. (2012). Securitization of migration in Greece: Process, motives, and implications. International Political Sociology, 6(4), 390-408.

Kasimis, C. (2012). Greece: Illegal immigration in the midst of the crisis. Migration Policy Institute. Retrieved from http://www.migrationinformation.org/Profiles/display.cfm?ID=884

Khosravinik, M. (2009). The representation of refugees, asylum seekers and immigrants in British newspapers during the Balkan conflict (1999) and the British general election (2005). Discourse \& Society, 20(4), 477-498.

Kincaid, A. (2009). What they left behind - The Irish landscape after emigration. In M. P. Bullock \& P. Y. Paik (Eds.), Aftermaths: Exile, migration, and diaspora reconsidered (pp. 33-52). New Brunswick, NJ: Rutgers University Press.

Kleist, O. (2012). Migrant incorporation and political memories: Transformations of civic and communal belonging in Australia since 1949. In I. Glynn \& J. O. Kleist (Eds.), History, memory and migration: Perceptions of the past and the politics of incorporation (pp. 189-213). Basingstoke, UK: Palgrave Macmillan.

Konsta, A. M., \& Lazaridis, G. (2011). Plastic citizenship, (in)securities and processes of abjectification: The case of Albanian migrant women in Greece. In G. Lazaridis (Ed.), Security, Insecurity and migration in Europe (pp. 259-286). Aldershot, UK: Ashgate.

Koukoutsaki-Monnier, A. (2012). Deterritorialising the nation? Internet and the politics of the Greek-American diaspora. Nations and Nationalism, 18(4), 663-683.

Kushner, T. (2006). Remembering refugees: Then and now. Manchester/New York: Manchester University Press.

Laliotou, I. (2010). Remembering diaspora, forgetting the global? Emerging cosmopolitics in contemporary Greece. Journal of Modern Greek Studies, 28(2), 247-255.

Lentin, R. (2003). Pregnant silence: (En)gendering Ireland's asylum space. Patterns of Prejudice, $37(3), 301-322$.

Low, K. E. Y. (2012). Songs for the nation: Migrant pasts and global futures in Singapore. In I. Glynn \& J. O. Kleist (Eds.), History, memory and migration: Perceptions of the past and the politics of incorporation (pp. 214-236). Basingstoke, UK: Palgrave Macmillan.

Mousourou, L. (2003). Immigration and immigration policy in Greece and Europe. Athens: Gutenberg.

Núñez, X. (2002). History and collective memories of migration in a land of migrants: The case of Iberian Galicia. History \& Memory, 14(1-2), 229-258.

Reisigl, M., \& Wodak, R. (2009). The discourse historical approach. In R. Wodak \& M. Meyer (Eds.), Methods of critical discourse analysis (pp. 87-121). London, UK: Sage.

Roberts, N. (2005). Haitian and Dominican e/migration and the (re)construction of national identity in the poetry of the third generation. Small Axe, 9(2), 86-103.

Sapountzis, A., Figgou, L., Bozatzis, N., Gardikiotis, A., \& Pantazis, P. (2013). 'Categories we share': Mobilising common in-groups in discourse on contemporary immigration in Greece. Journal of Community \& Applied Social Psychology, 23(4), 347-361. 
Sibley, C. G., Liu, J. H., Duckitt, J., \& Khan, S. S. (2008). Social representations of history and the legitimation of social inequality: The form and function of historical negation. European Journal of Social Psychology, 38(3), 542-565.

Steiner, N. (2000). Arguing about asylum: The complexity of refugee debates in Europe. New York, NY: St. Martin's Press.

Tormey, A. (2007). Everyone with eyes can see the problem: Moral citizens and the space of Irish nationhood. International Migration, 45(3), 69-100.

Triadafilopoulos, T. (2003). The political consequences of forced migration transfers: Refugee incorporation in Greece and West Germany. In K. Schönwälder, R. Ohliger, \& T. Triadafilopoulos (Eds.), European encounters: Migrants, migration, and European societies since 1945 (pp. 99-122). Aldershot, UK: Ashgate.

Triandafyllidou, A. (2000). The political discourse on immigration in southern Europe: A critical analysis. Journal of Community and Applied Social Typology, 10, 373-389.

Triandafyllidou, A., \& Kouki, H. (2014). Naturalizing racism in the centre of Athens in May 2011: Lessons from Greece. Journal of Immigrant \& Refugee Studies, 12(4), 418-436.

Triandafyllidou, A., \& Maroukis, T. (2012). Migrant smuggling: Irregular migration from Asia and Africa to Europe. Basingstoke, UK: Palgrave Macmillan.

Triandafyllidou, A., \& Veikou, M. (2002). The hierarchy of Greekness: Ethnic and national identity considerations in Greek immigration policy. Ethnicities, 2(2), 189-208.

Tzanelli, R. (2006). 'Not my Flag!' Citizenship and nationhood in the margins of Europe. Ethnic and Racial Studies, 29(1), 27-49.

Van Der Valk, I. (2003). Right-wing parliamentary discourse on immigration in France. Discourse and Society, 13(3), 309-348.

Van Dijk, T. (1993). Elite discourse and racism. Newbury Park, CA: Sage.

Van Dijk, T. (1997). Describing others in western parliaments. In S. H. Riggins (Ed.), The language and politics of exclusion (pp. 31-64). London, UK: Sage.

Van Dijk, T. (2014). Discourse-cognition-society. Current state and prospects of the socio-cognitive approach to discourse. In C. Hart \& P. Cap (Eds.), Contemporary studies in critical discourse analysis (pp. 121-146). London, UK: Bloomsbury.

Van Leeuwen, T., \& Wodak, R. (1999). Legitimizing immigration control: A discourse historical approach. Discourse Studies, 1(1), 83-118.

Vogli, E. (2011). The making of Greece abroad: Continuity and change in the modern diaspora politics of a "historical" irredentist homeland. Nationalism and Ethnic Politics, 17(1), 14-33.

Voutira, E. (2003). Refugees: Whose term is it anyway? Emic and Etic constructions of "refugees" in modern Greek. In J. Van Selm, K. Kamanga, J. Morrison, A. Nadig, \& S. M. Špoljar-Vržina (Eds.), The refugee convention at fifty: A view from forced migration studies (pp. 65-79). Lanham, MD: Lexington.

Wodak, R. (2011). 'Us' and 'them': Inclusion and exclusion - Discrimination via discourse. In G. Delanty, R. Wodak, \& P. Jones (Eds.), Identity, belonging and migration (pp. 54-77). Cambridge: Cambridge University Press.

Wodak, R., de Cillia, R., Reisigl, M., \& Liebhart, K. (2000). The discursive construction of national identity. Edinburgh, UK: Edinburgh.

Zetter, R. (2014). Creating identities, diminishing protection and the securitisation of asylum in Europe. In S. Kneebone, D. Stevens, \& L. Baldassar (Eds.), Refugee protection and the role of law: Conflicting identities (pp. 22-35). Abingdon, Oxon: Routledge. 


\section{Appendix}

Table 1

List of Documents

\begin{tabular}{ll}
\hline Date & Topic \\
\hline December 11, 1996 & Asylum Law \\
\hline December 12, 1996 & Asylum Law \\
\hline March 06, 2001, morning & Immigration Law (Residence and Control) \\
\hline March 06, 2001, evening & Immigration Law (Residence and Control) \\
\hline August 02, 2005 & Immigration Law (Residence and Control) \\
\hline August 03, 2005, morning & Immigration Law (Residence and Control) \\
\hline August 03, 2005, evening & Immigration Law (Residence and Control) \\
\hline March 09, 2010 04,2005 & Immigration Law (Residence and Control) \\
\hline March 10, 2010 & Citizenship and Naturalization \\
\hline March 11, 2010 & Citizenship and Naturalization \\
\hline January 11, 2011 & Citizenship and Naturalization \\
\hline January 12, 2011 & Asylum and Return \\
\hline September 27, 2012 & Asylum and Return \\
\hline March 18, 2014 & Detention \\
\hline March 19, 2014 & Codification of Immigration Law \\
\hline March 20, 2014 & Codification of Immigration Law \\
\hline June 24, 2015 & Codification of Immigration Law \\
\hline July 07, 2015 & Citizenship and Naturalization \\
\hline July 08, 2015 & Citizenship and Naturalization \\
\hline
\end{tabular}

Table 2

Greek Governments and Political Parties

\begin{tabular}{|c|c|c|}
\hline Year & Government Party & Opposition Parties \\
\hline 1990-1993 & $\begin{array}{l}\text { New Democracy } \\
\text { (conservative) }\end{array}$ & PASOK, KKE (Greek Communist Party, 'old' left); \\
\hline 1993-1996 & $\begin{array}{l}\text { PASOK (Panhellenic Socialist } \\
\text { Movement, centre-left) }\end{array}$ & $\begin{array}{l}\text { New Democracy, KKE, Synaspismos (Coalition of Left } \\
\text { and Progress, New Left) }\end{array}$ \\
\hline $1996-2000$ & PASOK & $\begin{array}{l}\text { New Democracy, KKE, Synaspismos (Coalition of Left } \\
\text { and Progress, New Left) }\end{array}$ \\
\hline $2000-2004$ & PASOK & $\begin{array}{l}\text { New Democracy, KKE, Synaspismos (Coalition of Left } \\
\text { and Progress, New Left) }\end{array}$ \\
\hline $2004-2007$ & New Democracy & $\begin{array}{l}\text { PASOK, SYRIZA (Coalition of the Radical Left) LAOS } \\
\text { (Popular Orthodox Rally, radical right), KKE }\end{array}$ \\
\hline 2007- 2009 & New Democracy & $\begin{array}{l}\text { PASOK, SYRIZA (Coalition of the Radical Left) LAOS } \\
\text { (Popular Orthodox Rally, radical right) }\end{array}$ \\
\hline $2009-2011$ & PASOK & New Democracy, SYRIZA, LAOS, KKE \\
\hline $\begin{array}{l}2011 \text { (Nov)- } \\
2012 \text { (May) }\end{array}$ & $\begin{array}{l}\text { Interim Coalition Government } \\
\text { (PASOK, New Democracy, } \\
\text { LAOS) }\end{array}$ & SYRIZA, KKE \\
\hline $2012-2015$ & $\begin{array}{l}\text { Coalition Government } \\
\text { (New Democracy, PASOK, } \\
\text { Democratic Left [European } \\
\text { left party) }\end{array}$ & $\begin{array}{l}\text { SYRIZA, KKE, Chrysi Avgi (Golden Dawn, extreme right) } \\
\text { Independent Greeks (ultra-nationalist) }\end{array}$ \\
\hline $2015-$ & SYRIZA, Independent Greeks & New Democracy, PASOK, KKE, Chrysi Avgi \\
\hline
\end{tabular}

Source. Ministry of the Interior, Hellenic Parliament (2012). 